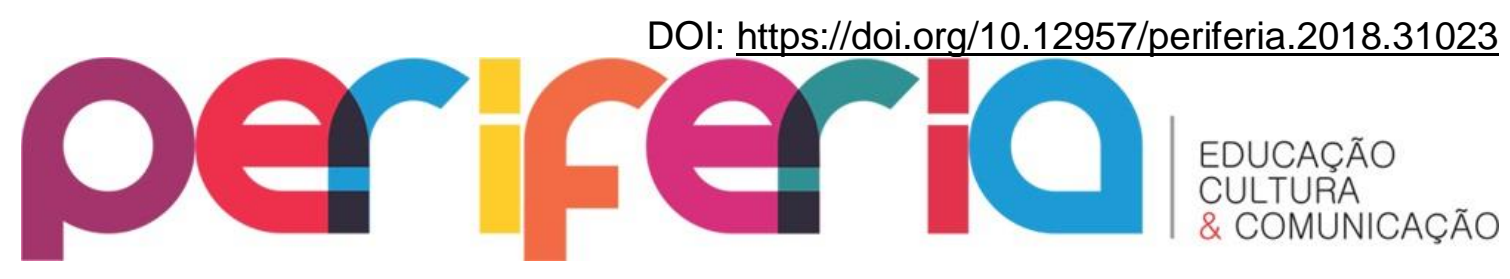

\title{
O GINGADO QUE VEM DA ÁFRICA: A CAPOEIRA NA CONSTRUÇÃO DA IDENTIDADE NEGRA NO BRASIL
}

\section{THE GIPSY WHO COMES FROM AFRICA: CAPOEIRA IN THE CONSTRUCTION OF BLACK IDENTITY IN BRAZIL}

\author{
Maressa Carolina Lopes Faria ${ }^{1}$ \\ Nayara Cristina Carneiro Araújo ${ }^{2}$
}

\begin{abstract}
RESUMO: A presente pesquisa analisa a influência da cultura africana na formação da identidade brasileira especificamente a partir da capoeira, discutindo identidade negra na capoeira. A questão principal é identificar se a valorização da influência africana a partir da capoeira é fator positivo no combate ao racismo, tendo em vista a percepção de indivíduos capoeiras. Para tanto, discute-se identidade a partir de Hall (2000) e Carvalho (2015), destacando a importância da cultura para a formação da identidade. Há ainda a análise dos primeiros registros iconográficos, o nascimento de uma nova tradição da capoeira (1930-1940) e o processo de folclorização e esportização (19501970), além do parecer que registrou a capoeira como patrimônio cultural do Brasil, utilizando-se de crítica bibliográfica como metodologia para a análise histórica. A discussão de identidade e a capoeira acontece a partir das colaborações de Areias (1983), Rego (1968) e Sodré (2002). Ao final, destaca-se como a capoeira é fundamental na valorização do negro e de sua história em nosso país, identificando as manifestações culturais negras, principalmente no que se trata da capoeira, incorporadas como contribuição para a cultura brasileira a partir do século XX.
\end{abstract}

Palavras-chave: África; Diáspora; Identidade; Racismo; Capoeira

ABSTRACT: This research analyzes the influence of African culture on the formation of Brazilian identity specifically from capoeira, discussing black identity in capoeira. The main question is to identify whether the valorization of African influence from capoeira is a positive factor in the fight against racism, considering the perception of

\footnotetext{
${ }^{1}$ Especialista em História e Cultura Afro-Brasileira e Africana pela (UFG) Universidade Federal de Goiás (2015) e Graduada em História pela UEG (universidade Estadual de Goiás) Campus Iporá- GO (2007).

${ }^{2}$ Doutoranda em Educação no Programa de Pós-Graduação em Educação da Universidade do Estado do Rio de Janeiro (PROPED/ UERJ), mestre em Educação pelo Programa de PósGraduação em Educação da Universidade Federal de Goiás (linha de pesquisa Educação, Trabalho e Movimentos Sociais), atuando principalmente em temas relacionados às juventudes. Possui título de especialista em Educação de Jovens e Adultos pelas Faculdades Integradas de Jacarepaguá (2011) e graduação em História pela Universidade Federal de Goiás (2010).
} 


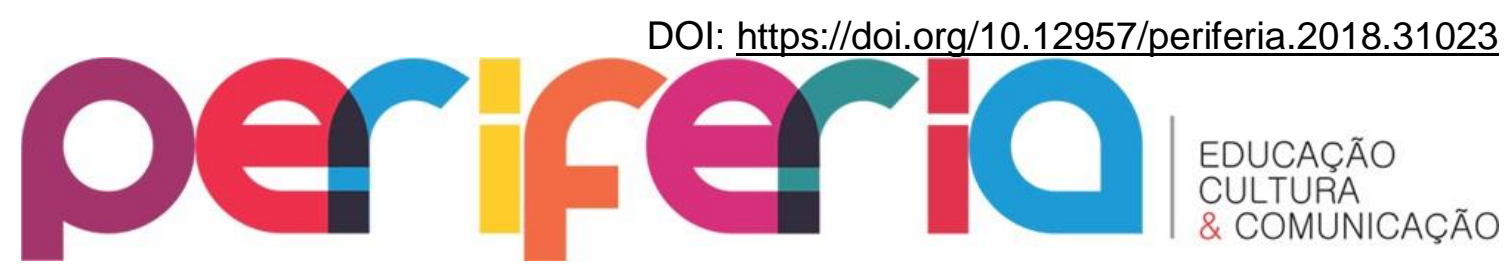

capoeira individuals. For that, identity is discussed from Hall (2000) and Carvalho (2015), highlighting the importance of culture for the formation of identity. There is also the analysis of the first iconographic records, the birth of a new tradition of capoeira (1930-1940) and the process of folklore and esportização (1950-1970), besides the opinion that registered the capoeira as cultural patrimony of Brazil, it is based on bibliographical criticism as methodology for historical analysis. The discussion of identity and capoeira comes from the collaborations of Areias (1983), Rego (1968) and Sodré (2002). At the end, it is important to note how capoeira is fundamental in the valorization of the Negro and its history in our country, identifying the black cultural manifestations, mainly in what is about capoeira, incorporated as contribution to Brazilian culture from the twentieth century.

Keywords: Africa; Diaspora; Identity; Racism; Capoeira

\section{O GINGADO QUE VEM DA ÁFRICA}

Desde o século XVI, milhares de africanos deixaram forçadamente o seu continente em direção ao Brasil para o trabalho escravo. O tráfico negreiro provocou um dos maiores deslocamentos populacionais da história da humanidade, pois o Brasil hoje concentra a maior população negra fora do continente africano. Apesar da dominação e exploração sobre esses sujeitos, existem marcas de sua presença na identidade histórica e cultural brasileira.

Mesmo com todas as barbaridades em que os negros foram submetidos durante o processo de escravidão no Brasil, percebe-se que não abandonaram sua identidade e cultura, chegando a transmiti-la para seus descendentes e influenciando na construção da identidade brasileira. Mesmo sob condições subumanas os africanos e afro-brasileiros não perderam sua identidade e deixaram registradas manifestações culturais que são muito importantes para a história brasileira. Durante o processo de escravidão, sua cultura negada e suprimida mantiveram vivas suas tradições chegando a reproduzir e deixar marcas e uma delas é a capoeira.

Para os africanos escravizados em nossas terras, a dança e a música sempre tiveram uma função social e religiosa. Durante esse período, a população negra tinha sua liberdade 


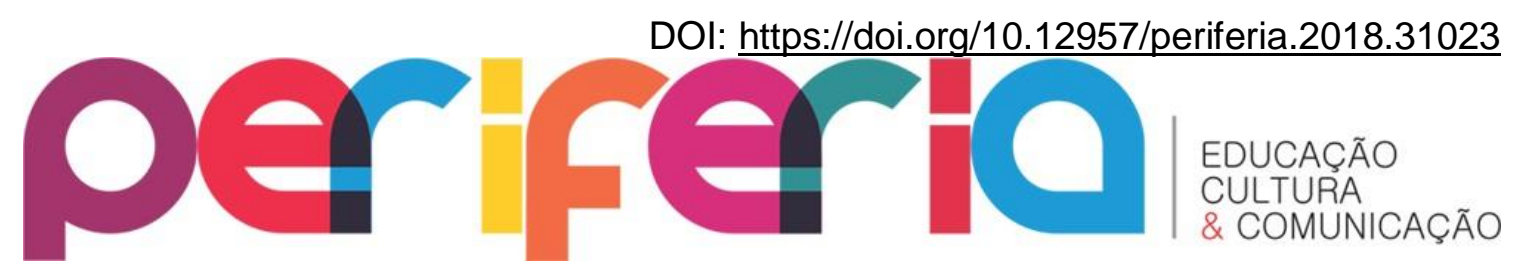

restrita só podendo recorrer ao canto e à dança para manter viva sua cultura e identidade. Através da mistura com outros povos e culturas, estilos musicais e danças ricas em espontaneidade foram surgindo e penetraram também todo o interior do país, uma delas é a capoeira. A capoeira é um exemplo das marcas deixadas pelos africanos no país e a cultura negra faz parte de nossa história.

De acordo com Areias (1983), a capoeira foi criada em terras brasileiras por africanos, tendo, assim, uma origem afro-brasileira, porém sua origem ainda é muito discutida. Para Rego (1968, p.31), "tudo leva a crer que seja uma invenção dos africanos no Brasil, desenvolvida por seus descendentes afro-brasileiros, tendo em vista uma série de fatores colhidos em documentos escritos". O autor chega a essa conclusão tendo em vista também o seu convívio com capoeiras que vivem na Bahia.

A importância que a capoeira e o negro tiveram na constituição do Brasil é imensurável. Fizeram a história e são parte dela, mesmo com todos os problemas enfrentados, como miséria, pobreza e preconceito, e acima de tudo sem o apoio do Estado

O presente estudo intenciona analisar a influência da cultura africana na formação da identidade brasileira especificamente a partir da capoeira. A pesquisa busca uma discussão onde a identidade negra na capoeira possa ser pensada ou mesmo repensada como produto de contatos e mistura de raças, já que nos dias atuais essa valorização cultural está se perdendo. A questão principal é identificar se a valorização da influência africana a partir da capoeira é fator positivo no combate ao racismo, tendo em vista a percepção que esses indivíduos capoeiras têm sobre as heranças africanas arraigadas em seu cotidiano.

Para tanto, identificaremos a questão da construção da identidade a partir de Hall (2000) e Carvalho (2015), destacando a importância da cultura para a formação da identidade. Após, analisaremos os primeiros registros iconográficos, o nascimento de uma nova tradição da capoeira (1930-1940) e o processo de folclorização e esportização (1950-1970), além do parecer que registrou a capoeira como patrimônio cultural do Brasil. Relacionaremos a discussão de identidade e a capoeira a partir das colaborações de Areias (1983), Rego (1968) e Sodré (2002). Ao final, destacaremos como a capoeira é fundamental na valorização do negro e de sua história em nosso país. 


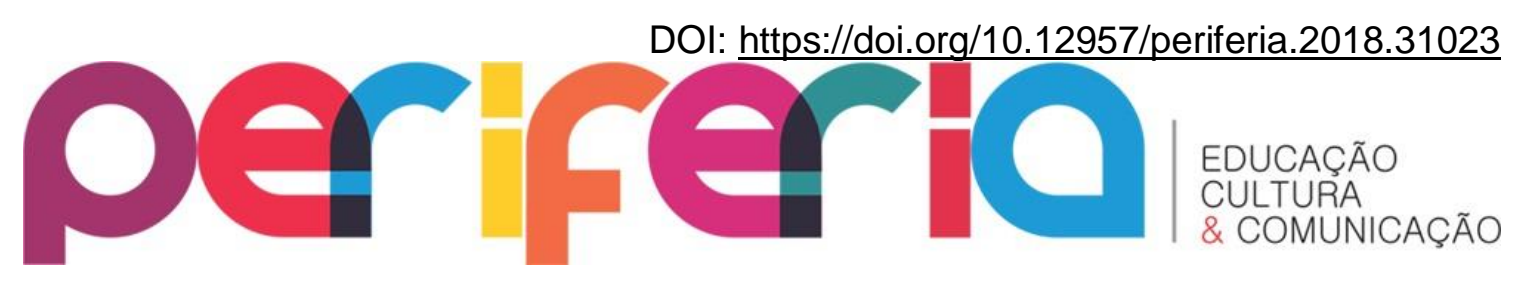

\section{A CAPOEIRA NA CONSTRUÇÃO DA IDENTIDADE NEGRA NO BRASIL}

Presente na história do Brasil há muito tempo, a capoeira foi tratada de maneira secundária nas pesquisas por um longo período, passando a figurar como objeto privilegiado de reflexão somente nas últimas décadas, "alguns autores se debruçaram sobre a prática da capoeira no século XIX, focando seus estudos principalmente sobre o Rio de Janeiro, cidade que, juntamente com Salvador e Recife, era um dos cenários mais importantes da capoeiragem no Brasil naquele momento" Fonseca (2009, p.18). Hoje, encontramos um número significativo de trabalhos, que abordam a capoeira em sua especificidade, também a relacionando com conceitos como memória, tradição e identidade. Entre esses trabalhos, destacaremos os de Santos (2004), Fonseca (2009) e Costa (2007).

A primeira autora discute a capoeira e a construção da identidade étnico cultural em Salvador/BA, refletindo-a como uma prática cultural do período da escravidão do negro no Brasil, com raízes africanas, mas que foram reelaboradas em solo brasileiro. Apresenta-nos a capoeira como prática cultural que é espaço de educação, de afirmação e construção da identidade. "É afirmação, pois apesar de ser um movimento, está ligada a herança cultural africana e construção pela formação da identidade no processo das contradições históricas" (SANTOS, 2004, p. 49-50).

Santos (2004) trata em sua pesquisa da identidade étnico cultural, considerando que a identidade produzida no grupo de capoeira parte de pressupostos étnicos (re) elaborados historicamente em Salvador. Dessa forma, discute a prática pedagógica desses grupos e considera uma ação transformadora, onde o objetivo último de um grupo de capoeira é formar o capoeirista, Santos (2004). Assim delimita os grupos de capoeira como espaço educativo, onde há seleção de conteúdos, procedimentos metodológicos e avaliação do que o indivíduo está aprendendo de capoeira.

A sociedade brasileira apresenta três matrizes culturais: a indígena, a africana e a ocidental, os grupos étnicos africanos conseguiram reelaborar sua herança cultural nesse quadro de tensões, onde a escravidão e o racismo reinavam. Dentro dessas matrizes culturais se encontram os maiores debates sobre a origem da capoeira: africana, brasileira ou indígena. Há autores que defendem as singularidades, e ao longo do século $\mathrm{XX}$ foram surgindo versões de 


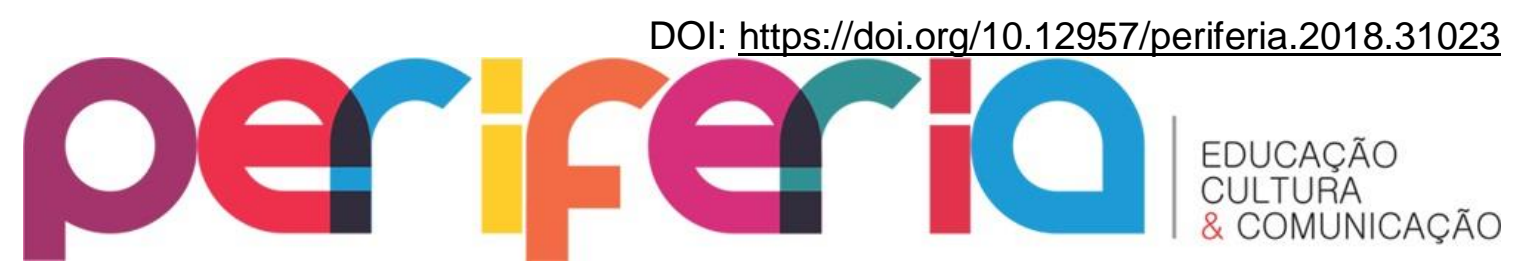

origem da capoeira como afro-americana e afro-brasileira. Santos (2004) compartilha da ideia de origem da capoeira afro-brasileira a partir dos argumentos de Soares (2002), onde a capoeira se estabelece enquanto uma reelaboração de manifestações culturais ancestrais feitas por africanos em território brasileiro.

A capoeira passa por vários momentos em sua história em terra brasileira, sendo considerado um ato criminoso em 1890 e alvo de discussões de intelectuais no século XX, quando discutem a sua prática como elemento da cultura brasileira questionando as suas origens e defendendo ser um esporte nacional. A partir daí deixa de ser ilegal e passa a ser praticada inclusive pela classe média, o que antes não acontecia, pois era vista como ambiente de marginalidade. Segundo Santos (2004, p. 48), "as contradições implícitas na construção da história da capoeira produzem uma identidade ambígua, a identidade do negro capoeirista que lutou e usou como resistência e a do malandro, vagabundo e desocupado". A preleção sobre o malandro é ideológica, construída em uma visão preconceituosa, pois em grande maioria os capoeiristas eram trabalhadores.

O período de colonização do Brasil deixou marcas profundas nos negros escravizados e percebemos que ainda existem resquícios desse processo, como o racismo e o preconceito. Foi através de muitas lutas e resistência que preservaram suas tradições e recriaram ou reelaboraram suas práticas culturais. Por isso Santos (2004, p.49-50) fala em seu trabalho sobre construção/afirmação de identidade, pois:

É construção por entendermos a formação da identidade na dinâmica das contradições históricas: se num certo momento foi preciso ir para o confronto até mesmo físico, em outro foi necessário recuar, camuflar as práticas culturais. È afirmação porque, apesar de ser movimento, está profundamente ligada a herança africana. Assim, é que trabalhamos com o binômio construção/afirmação. Ele expressa tensão, movimento, processo.

No início do século XX com o mito da democracia racial, a capoeira adquire status nacional e passa a ter uma maior aceitação, chegando a ser autorizado pelo Estado o funcionamento da academia do Mestre Bimba, em 1937, representante da capoeira regional. A capoeira regional de Mestre Bimba se contrapunha a capoeira Angola de Mestre Pastinha, pois incorporava elementos estranhos à cultura estritamente africana, sendo um projeto mestiço, ao

Revista Periferia, v.10, n.1, p. 179 - 201, Jan./Jun. 2018 


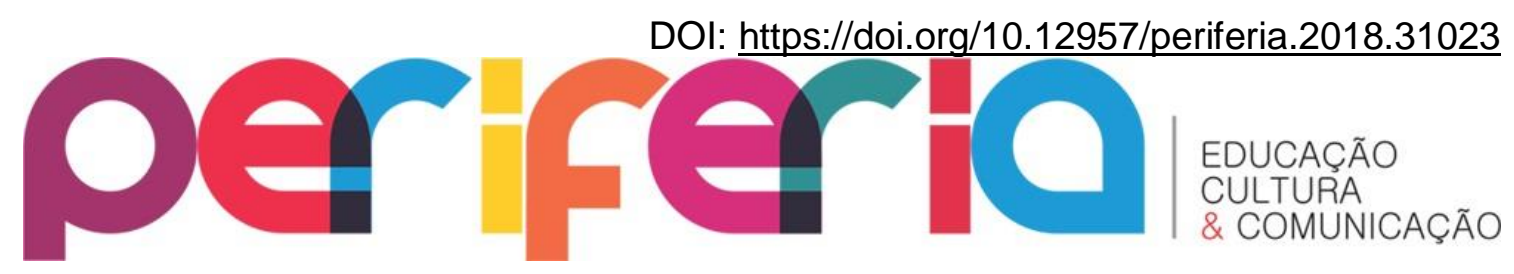

contrário da capoeira Angola que mantinha seus elementos originais e reafirmava seus valores. Apesar das contradições, as duas formas influenciavam o negro em sua redefinição social no país.

Sobre os conflitos de tradição na capoeira, especificamente a partir das tendências Angola e Regional em 1930, cabe uma análise do trabalho de Fonseca (2009). A memória é tratada no sentido da compreensão de como os mestres de capoeira constroem e recuperam seu passado, formando assim fronteiras identitárias dos diversos grupos organizados, tendo em seu trabalho como principal fonte a história oral. Segundo Fonseca (2009), "por mais que praticantes e pesquisadores usualmente falem em capoeira no singular, ela se configura como um campo bastante heterogêneo, subdividida em diversos grupos e estilos". Cada mestre traz consigo um estilo e linhagem diferente e exerce a liderança do seu grupo, traz consigo práticas diferentes dos demais, destacando assim a pluralidade dessa arte e delimitando também as fronteiras identitárias dos grupos em que pertencem.

Assim como Santos (2004) retrata em seu trabalho, Fonseca (2009, p.36) discute minunciosamente em seu primeiro capítulo os caminhos que a capoeira trilhou no Brasil, desde quando era tratada como crime e marginalizada, até virar produto de exportação e atrair estrangeiros para o país em busca da arte, como afirma:

Presente em mais de 150 países, a capoeira é, hoje, um produto de exportação, trazendo milhares de estrangeiros todos os anos para o Brasil. Oferecida em creches, escolas, academias e clubes, a capoeira aparece como uma atividade em plena expansão na sociedade brasileira, muitas vezes colocada como diferencial e servindo de chamariz em muitos desses locais. Porém, se atualmente é lugar comum pensar na capoeira como uma atividade amplamente praticada e bem recebida em diversos espaços, em outros momentos históricos do nosso país não era essa a relação existente.

Faz parte da memória dos capoeiristas o período de discriminação e perseguição que sofreram no Brasil e com muita luta e resistência que conquistaram a posição atual em que se encontra. Todo o desenvolvimento e transformação da capoeira no país gerou um interesse de grupos que disputam a memória da capoeira autêntica, representada pelos Mestres Bimba e Pastinha, de acordo com Fonseca (2009), "somente mestres reconhecidos como detentores de um saber autêntico, ou seja, herdeiros de tradições reconhecidas enquanto legítimas, são 


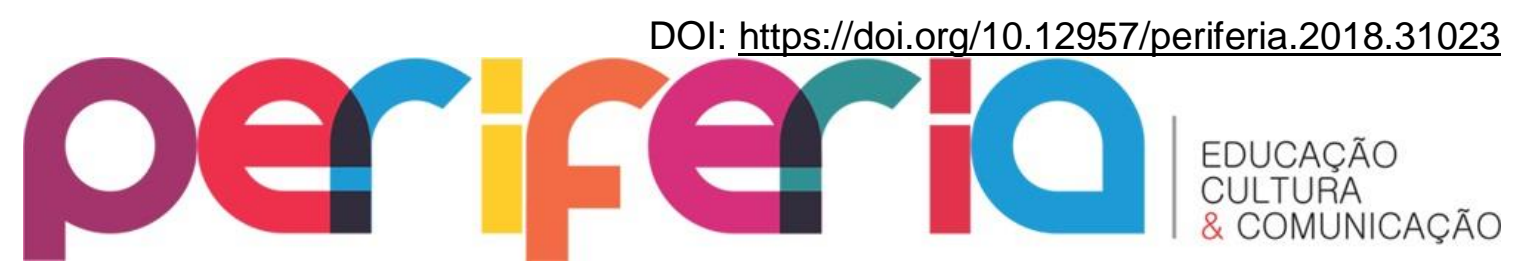

chamados a ministrar palestras pelo Brasil e pelo exterior". Dessa forma, esses mestres difundem práticas e memórias tipicamente brasileiras e que fazem parte da identidade do nosso povo.

A importância do conceito de memória no estudo da Capoeira dentro do trabalho do autor diz respeito ao caso de existir poucos registros escritos sobre a capoeira, assim a história oral é responsável pela transmissão dos saberes, práticas, ritos, movimentos e músicas dessa arte. Fonseca realizou pesquisas e entrevistas com mestres do Rio de Janeiro para saber como eles interpretam o passado e como constroem certas memórias, são vistos dentro de seus grupos como porta-vozes e exercem um papel de liderança, onde suas falas e decisões são legitimadas. Percebe-se nas entrevistas que mesmo alguns mestres não terem concluído seus estudos, julgam de extrema importância a vida escolar e incentivam seus alunos à concluí-los. Também nas entrevistas surge o empasse entre a Capoeira Angola e Regional, alguns deles como Mestre Vilmar 65, não concorda com a divisão da capoeira, afirmando que "essa cisão somente enfraquece a capoeira, ainda para Vilmar, a capoeira é uma só, não cabendo esta divisão já que cada pessoa jogaria de maneira diferente, conforme um jeito muito específico que ultrapassa qualquer escola" (FONSECA, 2009, p. 103-104).

Os mestres têm também, como foi verificado, a consciência da influência que exercem na vida dos seus alunos, assim fazem memória da importância que os seus antigos mestres tiveram para eles, como afirma a autora:

Igualmente, no momento atual, é valorizado o mestre que foi formado, que teve sua personalidade influenciada e, muitas vezes determinada, por um mestre cultuado hoje em dia. Para além dessas construções, as relações mestre/ discípulos na capoeira são, de fato, comumente muito estreitas. A ideia, sendo comum em praticamente todos os grupos e escolas, da capoeira como filosofia de vida, faz com que os mestres encarnem não só uma pessoa experiente em rodas de capoeira e que seria especialista em golpes, técnicas e especificidades da prática. Eles passam a ser, principalmente, pessoas que conquistaram uma sabedoria de vida diferenciada e, portanto, teriam uma grande "malícia" no jogo da capoeira (FONSECA, 2009, p.121).

Além disso, é importante que os mestres consigam congregar e tornar fieis seus alunos para que eles façam história dentro de seu grupo, levando seu nome para outros espaços 


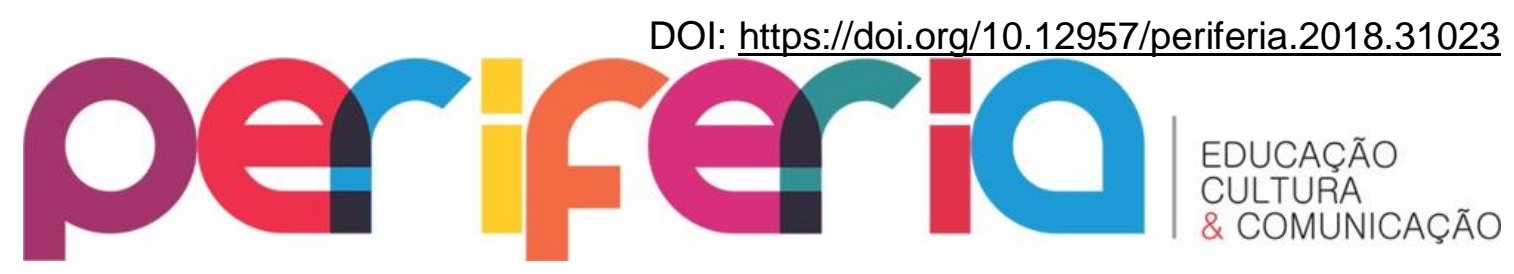

na sociedade. Por isso, a figura do mestre de capoeira reflete tanto respeito e são fundamentais para a efetivação de um grupo, adquirindo assim características próprias e uma identidade. Os alunos precisam ter também uma admiração pelo seu mestre, dessa forma ele mantém sua autoridade, o exemplo é a melhor forma de garantir essa valorização dos mesmos.

Ainda que exista a pluralidade dentro da capoeira, não se pode retirar a importância de seus praticantes para sua consolidação no Brasil e também para se tornar uma manifestação cultural que ganhou espaço inclusive internacionalmente. Criou-se dentro dessa relevância, uma disputa entre os grupos para uma maior visibilidade dos mesmos, uma busca incessante pela colocação de capoeira autêntica, notada e valorizada no país e no exterior.

Por Costa (2007), a capoeira já é analisada através de uma ótica do trabalho, como uma produção humana e também através de sua relação com a educação, especificamente a Educação Física. Na sua relação com o trabalho o autor cita os estereótipos criados no Brasil sobre as atividades desenvolvidas pelas pessoas, onde os que lidam com o intelecto e a ciência são considerados mais importantes e as atividades relacionadas ao fazer prático considerado menos importante. Porém o autor argumenta que:

Todo trabalho é importante, pois implica, como foi mencionado, em primeira e última instância, a humanização dos indivíduos. Todo trabalho é uma ação cultural e toda a cultura é trabalho, pois ambos são inerentes ao Homem, que somente assim pode ser chamado, porque, ao modificar conscientemente a natureza, produzindo trabalho e cultura, se torna humano. (COSTA, 2007, p.75).

O homem, nesse contexto do trabalho e cultura, cria e recria. Assim ocorreu com os negros escravizados no Brasil, "ao mesmo tempo em que tinham sua cultura negada e suprimida, não perderam totalmente sua identidade, expressa na força de criação de uma das manifestações da cultura popular mais importante na e para a história da nossa terra - a capoeira" (COSTA, 2007, p. 76).

Durante o processo de escravidão, os africanos trazidos ao Brasil como escravos viviam em condições subumanas, e mesmo com todas as repressões deixaram suas marcas e influenciaram na formação do povo brasileiro. Neste contexto de exploração de força de trabalho surge a capoeira, mesmo com muitas discussões a cerca de sua origem, se africana, ou

Revista Periferia, v.10, n.1, p. 179 - 201, Jan./Jun. 2018 


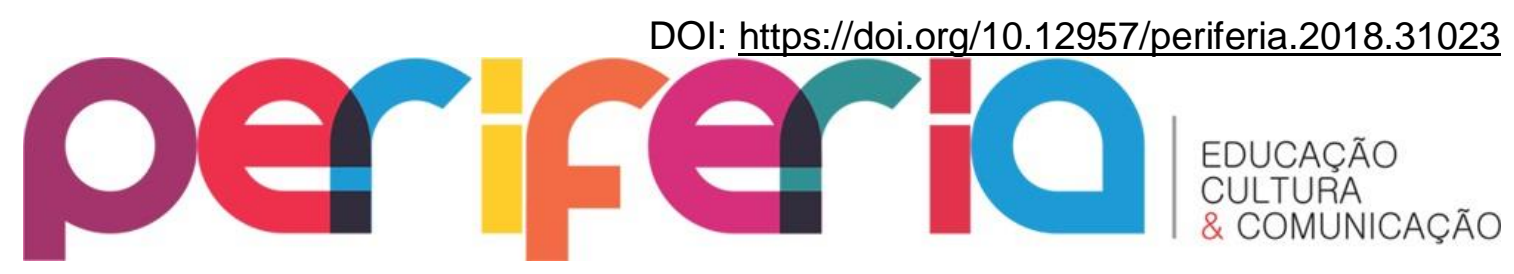

brasileira, ou afro-brasileira, o que não pode é deixar que sua importância seja questionada, pois faz parte da nossa cultura. No início a prática da capoeira era uma forma de resistência às condições impostas a eles, muitos anos depois pode ser considerada uma afirmação de sua cultura.

Após a abolição da escravidão, muitos negros sem perspectivas de trabalho e de uma vida fora das senzalas, continuaram em seus respectivos trabalhos. Os que saíram foram jogados às margens da sociedade e daí vem o estereótipo de que a capoeira é uma atividade de marginais, vagabundos e desocupados. Porém eles se mantiveram firmes e estabelecendo sua cultura e tentando desconstruir essas visões preconceituosas, principalmente em alguns Estados, como afirma Costa (2007, p.89):

No Rio de Janeiro, no Recife e na Bahia, a capoeira seguia sua história, e seus praticantes faziam a sua própria. Originavam-se de várias partes das cidades, das áreas urbanas e rurais, das classes mais abastadas às mais humildes, de pessoas de origem africana, afrobrasileira, europeia e brasileira, inserindo-se em vários setores e exercendo várias atividades de trabalho, profissões e ofícios.

No século XX, como conta o autor, os mestres de capoeira passam a vender sua força de trabalho no campo educacional, onde ele denomina de "pedagogização" da capoeira. O primeiro mestre a cobrar pelos seus ensinamentos e formar turmas organizadas, com horários determinados foi Bimba, isso após a criação da Capoeira Regional. Na década de 30 abriu uma escola para o ensino de capoeira, chamada "O clube de união em Apuros", daí por diante a capoeira vem sendo ressignificada constantemente, influenciada pelas áreas de Educação Física, do esporte e outros. Sua arte foi crescendo e chamando a atenção, atraindo assim novos olhares para a prática da capoeira, vindo atualmente a ser objeto de estudo para muitos acadêmicos e tendo inclusive um reconhecimento mundial.

A CONSTRUÇÃO DA IDENTIDADE

Revista Periferia, v.10, n.1, p. 179 - 201, Jan./Jun. 2018 


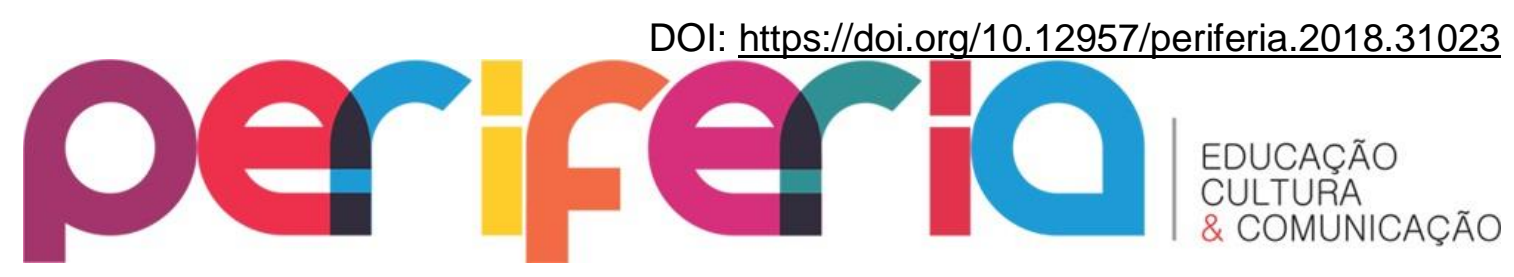

A pesquisa intenciona analisar a influência da cultura africana na formação da identidade brasileira especificamente a partir da capoeira. Para tanto, identificaremos a questão da construção da identidade a partir de Hall (2000) e Carvalho (2015), destacando a importância da cultura para a formação da identidade. O surgimento de novas identidades é acompanhado do declínio das velhas identidades, que por muito tempo estabilizaram o mundo social. Afinal, "a sociedade não é, como os sociólogos pensaram muitas vezes, um todo unificado e bem delimitado, uma totalidade, produzindo-se através de mudanças evolucionárias a partir de si mesmas" (Hall, 2006 p. 17). Hoje, vivemos em uma sociedade de contingências. Isso significa que há diversas formas de se relacionar, várias combinações que podem ser feitas diferentes das já feitas.

Na obra em questão, Hall (2006) trabalha com três concepções de identidade, sendo elas sobre o indivíduo do Iluminismo, o indivíduo Sociológico e o Pós-moderno. Ele destaca que a primeira concepção fala sobre um indivíduo centrado, unificado, e tipicamente cartesiano, sendo o centro de tudo, principalmente destacando a questão da razão humana; o segundo fala sobre um indivíduo social, destacando as relações humanas e a formação da identidade a partir do diálogo do eu com o mundo exterior a mim; e o terceiro sendo o indivíduo provisório, instável, em constante formação, sendo hoje o que não necessariamente será amanhã.

Sobre o sujeito do iluminismo, destaca-se a seguinte afirmação do autor: "O centro essencial do eu era a identidade de uma pessoa. Direi mais sobre isto em seguida, mas pode-se ver que essa era uma concepção muito "individualista" do sujeito e de sua identidade" (Hall, 2006, p. 11).

Sobre o sujeito sociológico, destaca-se:

De acordo com essa visão, que se tornou a concepção sociológica clássica da questão, a identidade é formada na "interação" entre o eu e a sociedade. O sujeito ainda tem um núcleo ou essência interior que é o "eu real", mas este é formado e modificado num diálogo contínuo com os mundos culturais "exteriores" e as identidades que esses mundos oferecem (...). A identidade, então, costura (ou, para usar uma metáfora médica, "sutura") o sujeito à estrutura. Estabiliza tanto os 


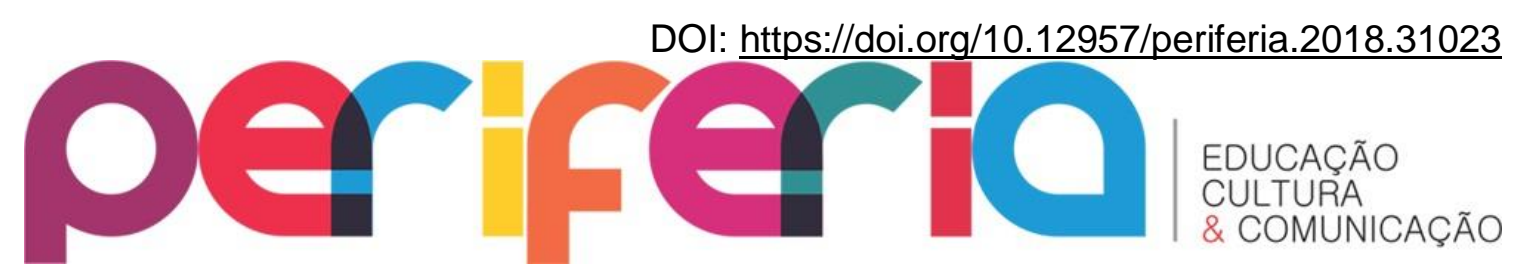

sujeitos quanto os mundos culturais que eles habitam, tornando ambos reciprocamente mais unificados e predizíveis (Hall, 2006, p.11)

No entanto, Hall destaca que o próprio processo de identificação do indivíduo sociológico impulsiona a compreensão da identidade pós-moderna, pois a projeção cultural tem o mundo exterior cada vez mais provisório, variável e problemático. Assim, destaca sobre o sujeito pós-moderno que esse "sujeito assume identidades diferentes em diferentes momentos, identidades que não são unificadas ao redor de um "eu" coerente. Dentro de nós há identidades contraditórias, empurrando em diferentes direções, de tal modo que nossas identificações estão sendo continuamente deslocadas". (Hall, 2006 p.13)

A modernidade tardia gerou impactos sobre a identidade cultural, pois as sociedades modernas estão em constante mudança. Com o sujeito moderno veio um individualismo diferente do que era vivido nas sociedades pré- modernas. O Humanismo e o Iluminismo trouxeram um status diferente ao homem, onde se tem uma representação como o autor coloca de o "indivíduo soberano" (Hall, 2006 p. 25). O homem passa a ser visto como agente de mudança, tendo suas capacidades exaltadas e se tornando figuras importantes neste processo de transformações. Neste sentido Hall (2006 p. 30) destaca:

Emergiu, então, uma concepção mais conceitual do sujeito. O indivíduo passou a ser visto como mais localizado e "definido" no interior dessas grandes estruturas e formações sustentadoras da sociedade moderna. Dois importantes eventos contribuíram para articular um conjunto mais amplo de fundamentos conceptuais para o sujeito moderno. $\mathrm{O}$ primeiro foi a biologia darwiniana. $\mathrm{O}$ sujeito humano foi "biologizado" - a razão tinha uma base na Natureza e a mente um "fundamento" no desenvolvimento físico do cérebro humano. O segundo evento foi o surgimento das Ciências Sociais.

A identidade, assim como a cultura está sempre em processo de formação, dessa forma pode-se afirmar que "a identidade é realmente algo formado, ao longo do tempo, através de processos inconscientes, e não algo inato, existente na consciência no momento do nascimento" (Hall, 2006 p. 38). Ou seja, deve-se falar de um processo de identificação não como algo acabado, mas em andamento, pois há uma busca constante em preencher o que ainda não está 


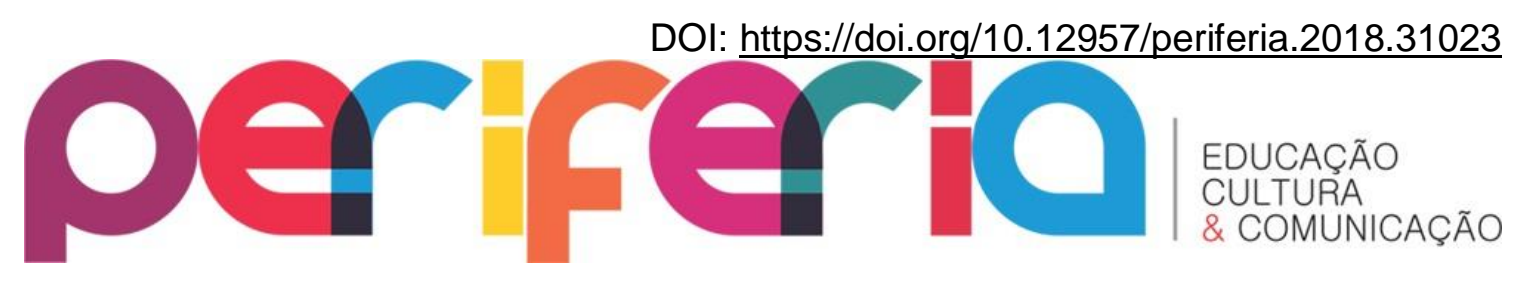

completo e inteiro em nós buscando elementos do nosso exterior. Existe a tentativa de se criar mundos estáveis, mas sempre existem significados que são exteriores e que não temos controle sobre eles, assim subverterão nossas tentativas.

A cultura sempre esteve como objeto de debate, porém no século XX vem a ser mais referenciada, as Ciências Humanas e Sociais reconhecem há tempos a sua importância. Para as Ciências Humanas no estudo das artes, das linguagens, das ideias filosóficas, nas Ciências Sociais, para a Sociologia em especial, pois é fator diferencial na "ação social”. Segundo Hall (1997), toda ação social é “cultural”, e todas as práticas sociais expressam ou comunicam um significado e, neste sentido, são práticas de significação.

Uma "revolução cultural" vem acontecendo na sociedade moderna, onde a revolução da informação e o intercâmbio de culturas favorecem as trocas de informação, conhecimento e ideias. No século XX, a indústria cultural é mediadora de muitos processos dessa tal revolução. Os produtos que circulam fazem parte de um mercado global, onde um grande contingente de pessoas tem acesso. Porém esses produtos disponíveis por essa revolução não podem ser equiparados a conquistas de outros momentos históricos, como o Renascimento italiano, por exemplo.

Devido a essas transformações há uma tendência de homogeneizar a cultura, tornando assim o mundo um lugar único, onde não haveria características próprias de grupos sociais que seriam assim distintos. Porém Hall (1997, p.03) ressalta que "as consequências desta revolução cultural global não são nem tão uniformes nem tão fáceis de ser previstas da forma como sugerem os homogeneizadores mais extremados". O autor salienta que existem pontos negativos desse processo, como a exportação cultural do ocidente que é bem mais desenvolvido do ponto de vista tecnológico, interferindo na definição do modo de vida das outras nações.

A cultura necessita da diferença, assim todas as transformações da revolução cultural acarretarão em uma ressignificação e em novas identificações, não necessariamente em uma cultura homogênea.

O resultado do mix cultural, ou sincretismo, atravessando velhas fronteiras, pode não ser a obliteração do velho pelo novo, mas a criação de algumas alternativas híbridas, sintetizando elementos de 


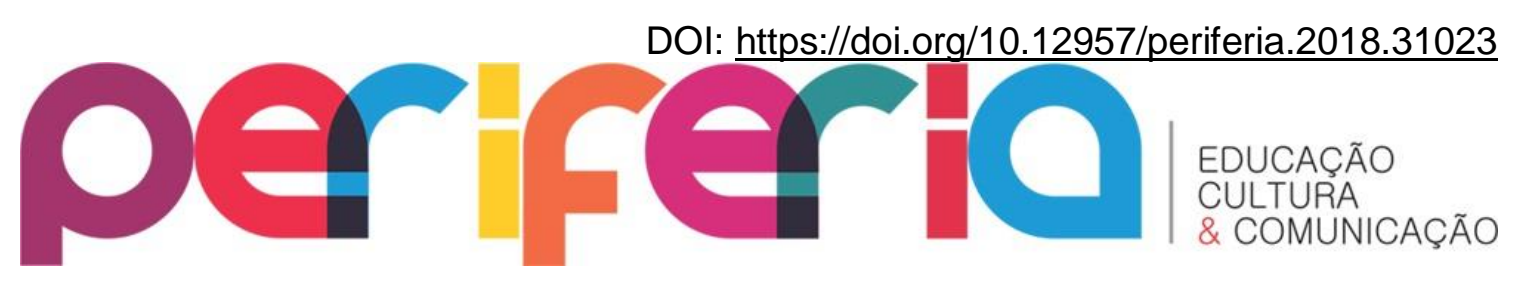

ambas, mas não redutíveis a nenhuma delas - como ocorre crescentemente nas sociedades multiculturais, culturalmente diversificadas, criadas pelas grandes migrações decorrentes de guerras, miséria e das dificuldades econômica do final do séc. XX. (HALL, 1997 p. 03)

A revolução cultural gerou mudanças globais, inclusive em forma de resistência, como é o caso do fundamentalismo islâmico no Oriente Médio, porém atingiu também o que o autor denomina de microcosmo, ou seja, a vida cotidiana das pessoas. $\mathrm{O}$ trabalho sempre fez parte do ser humano e percebe-se transformações consideráveis nesse campo, como exemplifica Hall (1997, p. 04), “o declínio do trabalho na indústria e o crescimento dos serviços e outros tipos de ocupação, com seus diversos estilos de vida, motivações, ciclos vitais, ritmos, riscos e recompensas". Essas transformações variam de um espaço geográfico para outro, mas não deixa de existir, são perpassadas pela quantidade de informação que recebemos e assim geram ressignificações nas diversas culturas, afinal a cultura está em tudo.

A expressão "centralidade da cultura" indica aqui a forma como a cultura penetra em cada recanto da vida social contemporânea, fazendo proliferar ambientes secundários, mediando tudo. A cultura está presente nas vozes e imagens incorpóreas que nos interpelam das telas, nos postos de gasolina. Ela é um elemento chave no modo como o meio ambiente doméstico é atrelado, pelo consumo, às tendências e modas mundiais (Hall, 1997, p. 05).

A cultura não é algo secundário, mas sim fundamental, inclusive interfere na identidade e na subjetividade das pessoas. A identidade é formada culturalmente, Hall (1997, p.08) salienta que "a identidade emerge, não tanto de um centro interior, de um eu verdadeiro e único, mas do diálogo entre os conceitos e definições que são representados para nós pelos discursos de uma cultura". Dessa forma só é possível pensar as identidades sociais através da cultura.

Elas são o resultado de um processo de identificação que permite que nos posicionemos no interior das definições que os discursos culturais (exteriores) fornecem ou que nos subjetivemos (dentro deles). Nossas chamadas subjetividades são, então, produzidas parcialmente de modo discursivo e dialógico. Portanto, é fácil perceber porque nossa compreensão de todo este processo teve que ser completamente reconstruída pelo nosso interesse na cultura; e por que é cada vez mais 


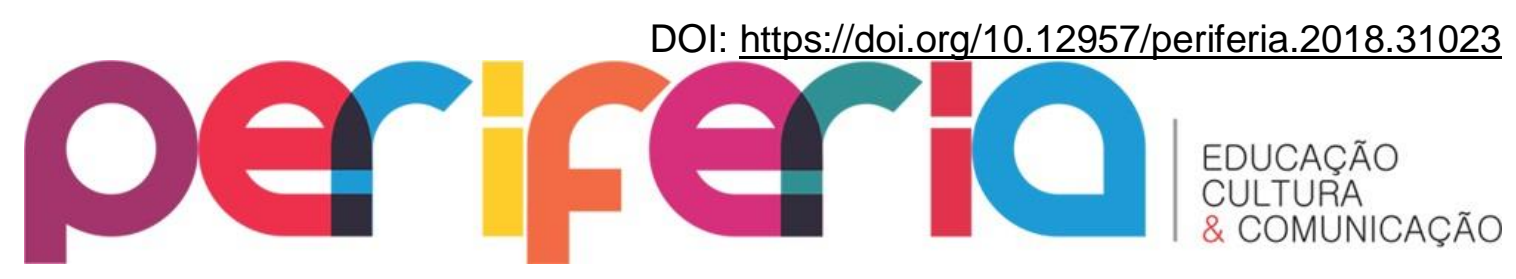

difícil manter a tradicional distinção entre interior e exterior, entre o social e o psíquico, quando a cultura intervém.

Os aspectos epistemológicos são analisados na obra em questão e denominado "virada cultural", onde um novo olhar sobre a cultura é desenvolvido, especificamente no que se refere a linguagem. Hall (1997, p. 10) destaca que "a virada cultural está intimamente ligada a esta nova atitude em relação à linguagem, pois a cultura não é nada mais do que a soma de diferentes sistemas de classificação e diferentes formações discursivas aos quais a língua recorre a fim de dar significado às coisas". Portanto esse termo está ligado à produção do conhecimento, já que pela linguagem e as representações que novas práticas vão surgindo e sendo colocadas em funcionamento.

A "virada cultural" provocou mudanças nas disciplinas tradicionais das Ciências Sociais, colocando-a de forma mais ampla em instituições e práticas que se forem analisadas tradicionalmente não fazem parte do que o autor chama de "esfera cultural". Assim, Hall (1997) argumenta que toda prática social tem sua dimensão cultural, mesmo as práticas econômicas ou políticas, pois possuem seus significados e estão "dentro do discurso". Dessa forma, "toda prática social tem condições culturais ou discursivas de existência”. (Hall, 1997 p. 14)

Analisando vários aspectos culturais o autor chega ao embate cultura e poder, devido à dimensão que os debates sobre a cultura chegaram é que surge a interrogativa de quem regula as práticas culturais. Hall (1997, p. 15) coloca que "a cultura e a mudança cultural são determinadas pela economia, pelo mercado, pelo Estado, pelo poder político ou social, no sentido forte da palavra (isto é, a forma da cultura é determinada por forças externas à cultura - econômicas ou políticas)". È importante analisar quem está por trás da regulação da cultura porque ela interfere efetivamente na vida do homem, assim o senso crítico precisa ser colocado em prática para analisar esse jogo de poder que influenciam as práticas culturais da sociedade.

Carvalho (2015) trabalha o conceito de identidade partindo da definição da palavra, que, portanto seria algo imutável, próprio, algo sempre idêntico. Aborda também o conceito de individual e coletivo, acreditando não ser possível separar identidade individual e coletiva, pertencemos a grupos com características e tradições com protótipo de identidade coletiva, dessa forma, há influência na formação da nossa identidade individual, da nossa personalidade. 


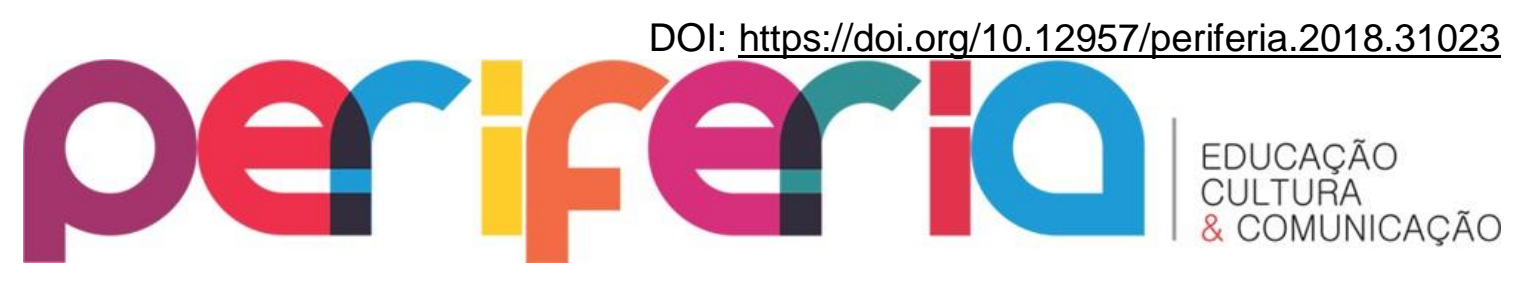

Porém, "até mesmo as identidades nacional, étnica, racial, familiar, de classe ou gênero, por mais dadas e "naturais" que pareçam, podem, no extremo, ser renegadas ou substituídas em virtude das experiências, opções e escolhas de cada indivíduo ao longo de sua trajetória de vida em sociedade". (Carvalho, 2015 p. 05)

O desejo de permanência está ligado ao conceito de identidade, daí surgem as crises de identidade. Fatores externos podem abalar, ameaçar esse desejo de permanência, podendo surgir assim o essencialismo identitário, que Carvalho $(2015$, p. 07) define "por fixar ou congelar a identidade em alguma qualidade do indivíduo ou grupo, tomada como uma essência, de caráter imutável e autorreferencial. É a manifestação mais extrema do desejo de permanência”. Dessa forma, pode existir um essencialismo de caráter histórico, caracterizado por um passado comum, congelado, e biológico, onde o conceito de identidade se apoia em critérios raciais, sexuais etc.

O essencialismo identitário ao fixar valores essenciais à indivíduos ou grupos pode provocar diversos tipos de racismo. Carvalho (2015, p. 08) afirma que "o racismo e o fundamentalismo são filhos diretos dos essencialismos identitários". Os estudiosos sobre identidade tendem a negar o essencialismo por se caracterizar em uma estagnação da identidade, impossibilitando se encontrar uma verdadeira identidade, preferem caracterizar a identidade como um processo em construção e não algo rígido e absoluto.

As identidades culturais não são rígidas nem, muito menos, imutáveis. São resultados sempre transitórios e fugazes de processos de identificação. Mesmo as identidades aparentemente mais sólidas, como a de mulher, homem, país africano, país latino-americano ou país europeu, escondem negociações de sentido, jogos de polissemia, choques de temporalidades em constante processo de transformação, responsáveis em última instância pela sucessão de configurações hermenêuticas que de época para época dão corpo e vida a tais identidades. Identidades são, pois, identificações em curso. (SANTOS, 2003, p. 135 apud CARVALHO, 2015, p.09).

Os processos de formação de identidade "são fruto, na falta de outra expressão, de uma relação dialética entre permanência e mudança" (Carvalho, 2015, p. 10). Dessa forma, um tende a estabilizar e outro a desestabilizar a identidade. Existe também a alternativa de haver 


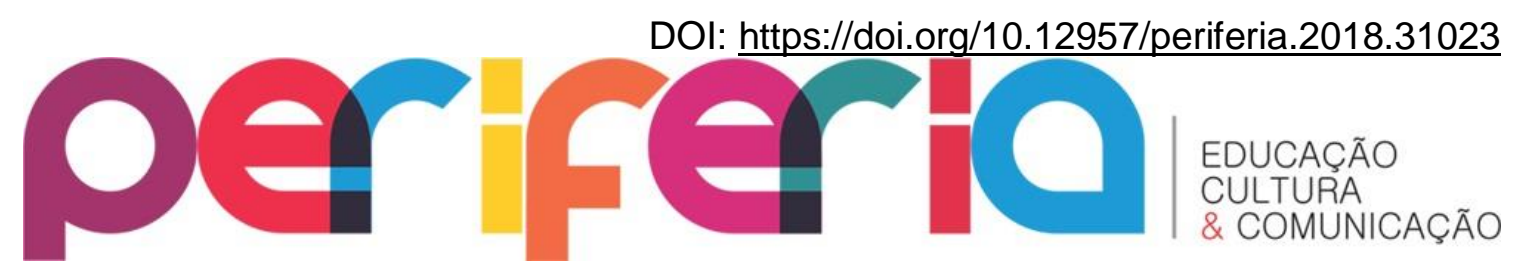

uma permanência no processo de mudança, um núcleo estável, o que o autor denomina de "marcador-mestre", podendo ser a cor, a etnia, a cultura, etc.

Dentro do conceito de identidade também encontramos a diferença, chamada nesse contexto de alteridade, que seria então a qualidade do outro, do que é diferente de nós. Carvalho (2015, p. 12) define que "é o que ocorre quando afirmamos algo do tipo sou brasileiro, branco, conservador, católico e homem, enquanto ela é argentina, negra, progressista, evangélica e mulher. Entretanto, por detrás de toda afirmação (o que sou) encontra-se invariavelmente uma negação ou diferenciação (o que não sou)". Nesses processos de identificação e diferenciação, sempre há comparações entre características próprias e alheias, reforçando a relação entre identidade e alteridade.

Carvalho (2015) se refere à característica das identidades, propriamente da identidade cultural como construção, mesmo com a presença do essencialismo identitário:

Mesmo a perspectiva do essencialismo identitário - que tende a conceber a identidade com algo dado, acabado, fixo, natural, prédeterminado - é questionada, nesse aspecto, mediante o argumento de que todo essencialismo seria ele próprio uma construção sociocultural, edificado dentro das relações sociais e não antes ou fora delas. Nesse sentido, ressaltar a identidade como construção é colocar em relevo seu contexto ou caráter processual, histórico e social; é destacar também os atores-sujeitos que as constroem, que as criam e recriam continuamente - daí serem sempre provisórias e contingentes -, conforme seus objetivos, expectativas, fantasias, necessidades, receios e temores. (CARVALHO, 2015, p. 15)

O autor em questão destaca sobre a identidade negra, abrangendo a questão de qual seria a matriz determinante na construção dessa identidade, devido a pluralidade cultural existente nesse processo. Nesse sentido conclui que "quer se trate de identidade negra, identidade racial, identidade étnica, identidade étnico-racial, identidade afro-brasileira ou identidade nacional, não importa, todas elas tendem a compartilhar certas características comuns que caracterizam as identidades" (Carvalho, 2015, p. 34). 


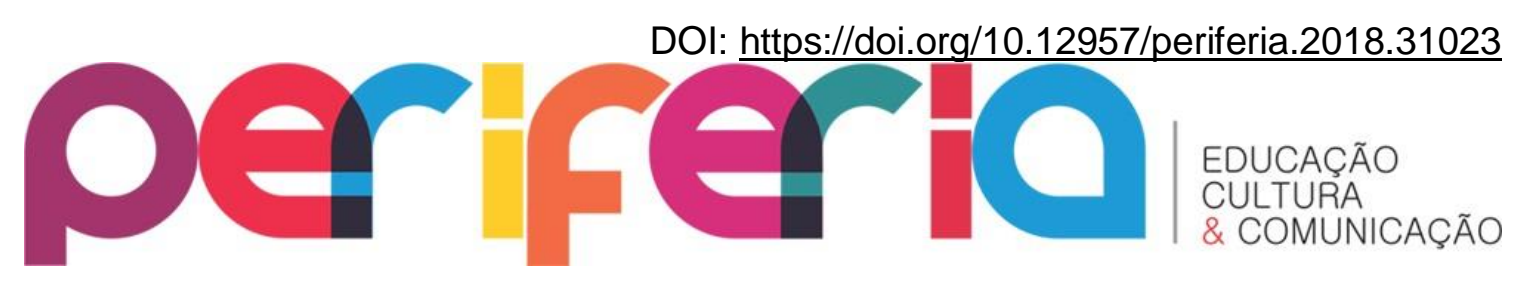

A CAPOEIRA NO BRASIL

Compreendendo a identidade como algo em constante construção, analisaremos os primeiros registros iconográficos, o nascimento de uma nova tradição da capoeira (1930-1940) e o processo de folclorização e esportização (1950-1970), além do parecer que registrou a capoeira como patrimônio cultural do Brasil. Já ressaltamos que no período da Primeira República a capoeira era considerada crime, porém no momento histórico brasileiro denominado Era Vargas (1930-1945) há a inclusão da capoeira nos currículos escolares e também uma ressignificação da mesma. Segundo Costa (2007, p. 61) é uma "época determinante do envolvimento da capoeira com a formulação de uma nova concepção de corpo, de atividade física e de Homem, para a nossa sociedade".

No início da década de 1940 a capoeira foi sistematizada como ginástica e o responsável por esse projeto é Inezil Penna Marinho, com a colaboração de outros professores e de Antônio Batista Pinto (Mestre Zulu). De acordo com Costa (2007), nessa ocasião surgem no Rio de Janeiro várias obras que tentam desvincular a imagem da capoeira com o universo marginal. Em outros estados, como na Bahia isso também ocorre, onde "o desenvolvimento dessas ações tem como ponto de partida os anos de 1938 a 1942, com a ênfase e o incentivo às atividades físicas do então governador Landulfo Alves de Almeida" (Costa, 2007, p. 68). Entretanto, na Bahia, são os próprios profissionais e ligados a capoeira que são os autores dessas modificações, e é no estado baiano que a tentativa de criar uma ginástica nacional ganha força, influenciados por Mestre Bimba e sua Luta Regional Bahiana.

No entanto, a capoeira ainda era proibida por lei. Somente em 1941 libera-se a prática da capoeira, mas com controle do Estado e em lugares determinados. Esse foi um ato interessante para o governo naquele contexto histórico. Costa (2007, p. 69) ressalta: 


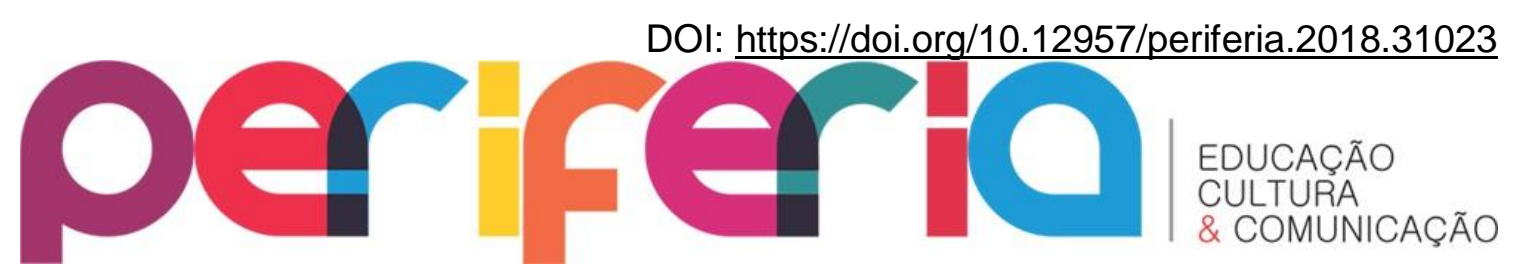

A revolução de 1930, que tinha à frente Getúlio Vargas, tomou como missão a reorganização do país, embora, para isso, precisava de apoio popular. Por isso, seu governo resolve libertar as válvulas de escape do povo discriminado e sofrido, ou seja, suas manifestações, ao mesmo tempo em que exerce certo controle da situação, estabelecendo regras e normas a serem cumpridas para a sua realização.

A capoeira, assim, poderia ser praticada, mas desvinculada de atos considerados marginais. Poderia também ser apresentada em festas populares e folclóricas, como luta somente em ambientes fechados e por pessoas "de bem", e assim se tornara esporte nacional. Mestre Bimba se apresenta em 1953 para Getúlio Vargas, então Presidente da República e ele na ocasião ressalta a capoeira como sendo "o único esporte verdadeiramente nacional" (Costa, 2007, p. 71). As inovações da Regional ressignificavam a capoeira e se adequavam as imposições do Estado Novo:

Além do envolvimento da capoeira como um todo, compreendemos que mais precisamente a Regional foi atingida em cheio, porque, nessa época, Mestre Bimba e essas modificações se constituíram no centro das atenções. Mas se faz importante destacar que a Capoeira Angola também sucumbiu, embora de forma diferenciada, aos constantes processos da dialética cultural.

Reis (1997 apud Costa 2007) “acredita que tanto a Regional de Bimba quanto a Angola de Pastinha foram ressignificadas a partir do que ela chama de movimento de transformação da capoeira em esporte branco, a partir do projeto da ginástica brasileira”. É importante salientar também que a Educação Física esteve influenciando a capoeira desde as práticas ligadas às forças armadas, que dominavam os métodos de ginástica. Porém, o mestre Bimba decide que a capoeira não necessitava desses métodos e retoma as aulas, através da própria Capoeira.

Contudo, posteriormente, podemos perceber que outros mestres da mesma época de Bimba, já no final da década de 60, utilizavam métodos ginásticos para ministrarem suas aulas de capoeira e descobrimos também que as aulas de Bimba, mais uma vez, foram envolvidas indiretamente por esses métodos. Realmente, a Capoeira Regional foi influenciada pela sociedade da época, através dos métodos de ginástica, e Mestre Bimba, mesmo não concordando, acabou de um modo ou de outro, permitindo essa interferência, 


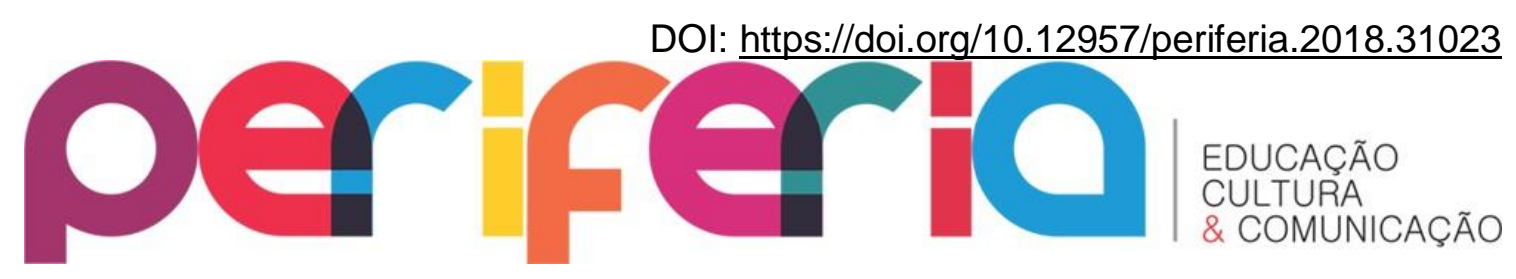

embora esse procedimento retarde a aula propriamente de capoeira. (COSTA, 2007, p. 73)

Em 1941 Mestre Pastinha legaliza a sua escola de capoeira. Ele a chama de Centro Esportivo e deixa claro que através de sua capoeira denominada Angola, manteria uma tradição autêntica, enquanto esporte. Segundo ele, o angoleiro deveria "conhecer o ritual, saber brincar e ser malicioso muito mais do que ter uma simples eficiência marcial dos golpes" (Fonseca, 2009, p. 66). Diferenciava-se assim da Regional que, para ele, era puramente marcial.

No Brasil entre 1930 e 1940 surge intelectuais com interesses em pesquisas sobre as manifestações culturais, entre eles Jorge Amado, Gilberto Freyre e Édison Carneiro. Há assim uma nova visão em relação a cultura afro-brasileira, onde são mais discutidas em Congressos, nas universidades e em todo âmbito social, inclusive Édison Carneiro foi um dos que organizaram o II Congresso Afro-Brasileiro em 1937. Esses acontecimentos eram importantes para o povo negro, era uma forma de protestar e reivindicar em favor de suas manifestações culturais, nesse período a visibilidade na imprensa ganha uma dimensão maior também, pode-se afirmar isso pela grande quantidade de dados encontrados no momento.

No Brasil, houve um processo de reordenamento das práticas de capoeira nas décadas de 1950 e 1960. Nesse período inúmeros capoeiristas baianos se deslocam para o sudeste, principalmente para São Paulo de Rio de Janeiro. "Essa migração resultou em uma mistura de estilos de jogo, originando o que tem se convencionado chamar de Capoeira Contemporânea" (Fonseca, 2009, p. 73), sendo uma mistura das capoeiras Angola e Regional, com as capoeiras jogadas em São Paulo e Rio de Janeiro, denominadas capoeira de rua. A capoeira esporte, debatida no início do século XX, tem seu auge em 1960 e 1970, modificando as relações no seu interior. Foi um período importante para seus praticantes que procuravam uma afirmação social e também legitimá-la no sudeste brasileiro.

Nas décadas de 1960 e 1970 surge a proposta de criar uma capoeira de padrão único, procuraram dar ênfase a Capoeira esporte, e enquadrar o capoeirista como atleta. Relacionando esse fato como o momento histórico brasileiro, encontramos a ligação com o regime militar, vigente de 1964 a 1985. "Os militares procuravam valorizar as escolas de capoeira que buscavam se organizar dentro de padrões esportivos, como por exemplo, fazendo uso de uniformes e organizando campeonatos" (Fonseca, 2009, p. 80). Em 1972, a capoeira foi reconhecida como esporte, em uma portaria expedida pelo MEC. 


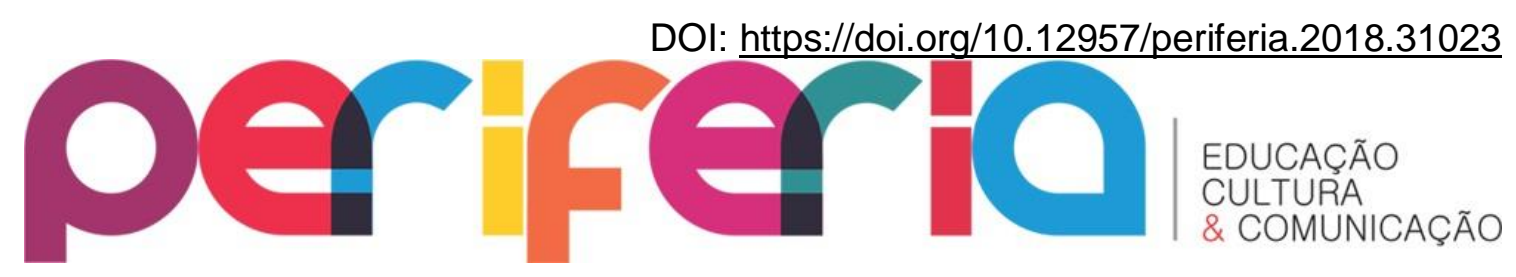

O objetivo da Coleção Dossiês dos Bens Culturais Registrados (Brasil, 2008) é tornar conhecidos e reconhecidos, como Patrimônio Cultural Brasileiro, os bens registrados de caráter imaterial. O $12^{\circ}$ volume dessa coleção diz respeito às características das Rodas de Capoeira e o Ofício dos Mestres de Capoeira, ressaltando essa manifestação cultural em território nacional. A arte da capoeira e também a sabedoria dos seus mestres são patrimônios vivos e são passados de geração em geração, porém mesmo com reconhecimento inclusive internacional, os mestres enfrentam dificuldades e até mesmo o esquecimento.

O dossiê tem o intuito de justificar a importância da capoeira como patrimônio cultural do Brasil e assim possui três linhas fundamentais: a pesquisa historiográfica, o trabalho de campo e a abordagem de temas relacionados à capoeira. $\mathrm{O}$ trabalho procura discutir o histórico da capoeira e descrever sua prática e suas particularidades, a Roda de Capoeira e o Ofício dos Mestres de Capoeira foram reconhecidos como patrimônio cultural brasileiro por meio da inscrição no Livro de Registro das Formas de Expressão e no Livro de Registro dos Saberes, volume primeiro, respectivamente, do Instituto do Patrimônio Histórico e Artístico Nacional, em 21 de outubro de 2008, conforme decisão proferida na $57^{\mathrm{a}}$ Reunião do Conselho Consultivo do Patrimônio Cultural, realizada no dia 15 de julho de 2008 (Brasil, 2008, p. 17).

A capoeira é uma manifestação cultural que tem característica de multiplicidade, envolve luta, dança e jogo. "Dessa forma, mantém ligações com práticas de sociedades tradicionais, nas quais não havia a separação das habilidades nas suas celebrações, característica inerente à sociedade moderna" (Brasil, 2008, p. 19). Os seus praticantes tem prioridades diferentes, alguns com interesse cultural, outros esportivos. Mas mesmo assim a diversidade não é deixada de lado. Devido a essa diversidade que é difícil delimitar as origens da capoeira em aspectos geográficos, culturais e também etimológicos.

A capoeira está presente como uma manifestação cultural importante até hoje, devido ao aprendizado repassado pelos mestres de geração em geração. Vale ressaltar que nesse longo processo ela se modificou, incorporou novas características e se ressignificou também. Atualmente está presente em vários segmentos em nossa sociedade, abrangendo espaços antes não alcançados. O Parecer do Iphan reconhece como patrimônio imaterial brasileiro, devido a sua importância para a construção da identidade do nosso povo, seu histórico afirma o seu valor para nossa cultura e há a necessidade de reconhecimento oficial da importância da capoeira pelo Estado Brasileiro. 


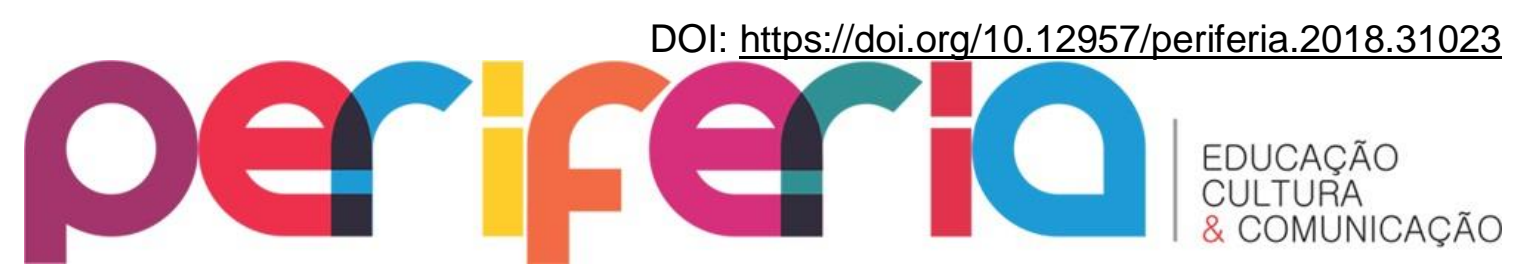

\section{ALGUMAS CONSIDERAÇÕES: A CULTURA AFRICANA NA FORMAÇÃO DA IDENTIDADE BRASILEIRA ATRAVÉS DA CAPOEIRA}

Após identificarmos a questão da construção da identidade, destacando a importância da cultura para a formação da identidade, analisando também os primeiros registros iconográficos, o nascimento de uma nova tradição da capoeira (1930-1940) e o processo de folclorização e esportização (1950-1970), além do parecer que registrou a capoeira como patrimônio cultural do Brasil, temos subsídios necessários para relacionarmos a discussão de identidade e a capoeira a partir das colaborações de Areias (1983), Rego (1968) e Sodré (2002), procurando destacar como a capoeira é fundamental na valorização do negro e de sua história em nosso país.

A condição de mercadoria em que os negros foram submetidos durante o processo de escravidão não foi suficiente para apagar da memória sua cultura e dessa forma reafirmaram sua identidade diante de tantas atrocidades em que eram subjugados. Sodré (2002, p.153) afirmou que o escravo passava pelo processo de transformação e apropriação cultural, ao se colocar em um novo espaço (terra), criando novas formas de identificação e pertencimento, por meio de relações históricas e sociais vivenciadas em "outro" contexto. "O carnaval, o futebol, as festas religiosas, foram jogos que os negros tomaram aos portugueses para constituir lugares de identidade e transação social”.

No fosso da escravidão encontramos os primeiros passos da capoeira no Brasil, vista como luta/dança, viveu um processo histórico marcado por inúmeras perseguições, gerando assim grandes embates na busca pela libertação de um povo que muito sofreu com o regime da escravidão (Areias, 1984), criando a capoeira para dar um significado à produção dos sentidos do negro. Percebe-se que mesmo com todo esse histórico a capoeira influenciou na formação da identidade do povo brasileiro, por um período foi vista como uma manifestação cultural de marginais, mas a duras penas afirmou sua tradição e conquistou seu espaço, inclusive 


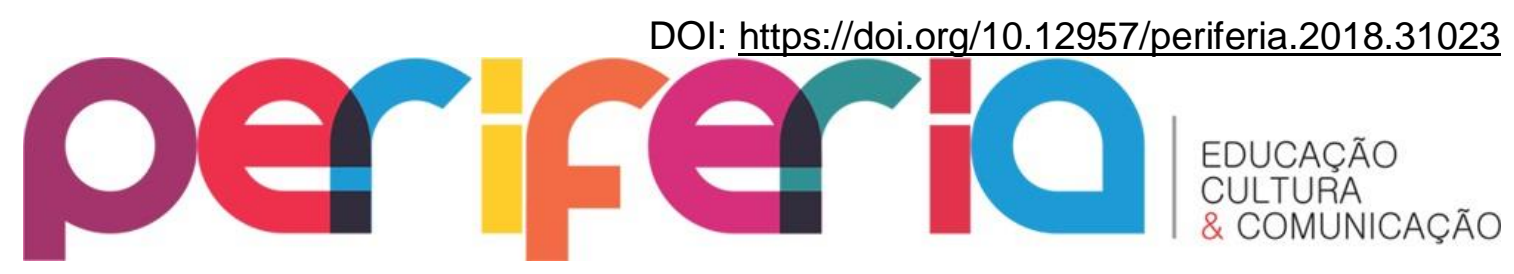

internacional. A valorização da influência africana a partir da capoeira é fator positivo no combate ao racismo, pois os capoeiras têm consciência sobre as heranças africanas arraigadas em seu cotidiano.

As manifestações culturais negras, principalmente no que se trata da capoeira, até então negadas e perseguidas, passam a ser incorporadas como contribuição para a cultura brasileira a partir do século XX. Deixam assim de fazer parte de um grupo étnico específico e de espaços delimitados para fazer parte do patrimônio cultural brasileiro e se espalhar pelos cinco continentes. Dessa forma tem influenciado no combate ao racismo, que ainda existe muito em nossa sociedade, mas já houve várias conquistas no que diz respeito à valorização da cultura afro-brasileira, um exemplo é o reconhecimento da capoeira como integrante da cultura brasileira.

De acordo com Rego (1968), levando em consideração fatores colhidos em documentos escritos, diálogos e convívio com antigos capoeiras, tudo leva a crer que a capoeira seja uma invenção dos negros africanos no Brasil. Analisando também as circunstâncias do surgimento da capoeira, Areias (1984, p. 156) afirma que os negros, por não possuírem armas suficientes para se defender, quase nem mesmo armas convencionais da época, precisaram adquirir uma forma de enfrentar as armas inimigas assim "utilizando se das estruturas das manifestações culturais trazidas da África como brincadeiras, competições, etc. que lá praticavam em momentos cerimoniais e ritualísticos (...) os negros criam e praticam uma luta de autodefesa para enfrentar o inimigo".

Independente de sua origem a capoeira ocupa uma posição de grande importância nas sociedades contemporâneas, através de suas atividades permite a construção de identidades coletivas e identidades nacionais além do processo de socialização de grupos sociais. Compreendendo identidade enquanto um processo de identificação em curso, submetido a todas as contingências da contemporaneidade, a capoeira no Brasil pode ser pensada e repensada como produto de contatos e mistura de raças, constituinte da identidade dos negros e, portanto, fundamental no fortalecimento da cultura africana em parâmetro nacional, regional e local, já que nos dias atuais essa valorização cultural está se perdendo e precisa se estabelecer nessas atividades que são muito além do que um esporte. 


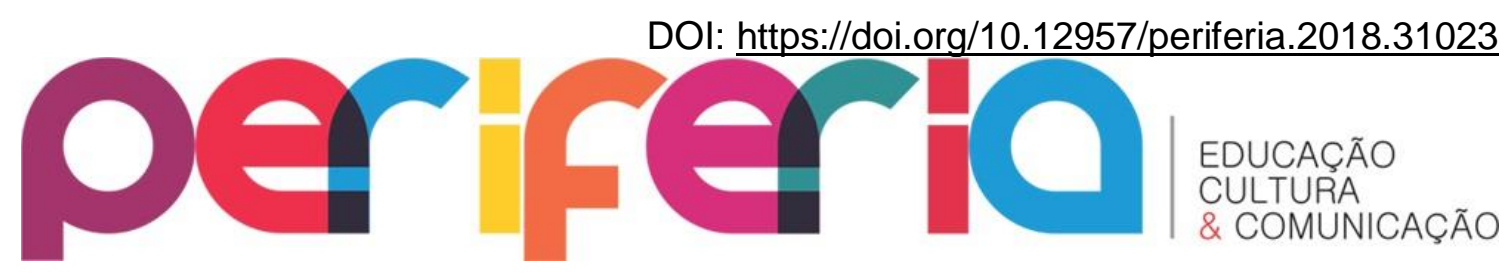

\section{REFERÊNCIAS BIBLIOGRÁFICAS}

AREIAS, Almir das. O que é Capoeira? São Paulo: Brasiliense, 1983.

BRASIL. Dossiê IPHAN: Rodas de Capoeira e Ofício dos Mestres de Capoeira. Brasil, 2008.

CARVALHO, Eugênio Rezende de. Identidades Culturais: contribuições para uma necessária reflexão teórica. Goiânia, 2015.

COSTA, Neuber Leite. Capoeira, trabalho e educação. Salvador, 2007.

FONSECA, Vivian Luiz. Capoeira Sou Eu: memória, identidade, tradição e conflito. Rio de Janeiro, 2009.

HALL, Stuart. A identidade Cultural na pós-modernidade. $10^{a}$ edição DP\&A Editora, 2006.

Quem precisa da identidade? In: SILVA, Tomaz Tadeu da. (Org.) Identidade e diferença: a perspectiva dos estudos culturais. Petrópolis, RJ: Vozes, 2000. p. 103-133.

A centralidade da cultura: notas sobre as revoluções culturais do nosso tempo. Educação \& Realidade, Porto Alegre, v. 22, n. 2, jul/dez. 1997.

REGO, Waldeloir. Capoeira Angola: Ensaio Sócio-Etnográfico. Salvador, Itapuã, 1968. SANTOS, Isabele Pires. Capoeira: Educação e Identidade Étnico-Cultural em grupos/academias da cidade de Salvador-BA. Revista Sitientibus: Feira de Santana, 2004.

SODRE, Muniz. Mestre Bimba: Corpo de Mandiga. Rio de Janeiro: Editora Manati, 2002.

O terreiro e a cidade: a forma social negro-brasileira. Salvador: Fundação Cultural do Estado da Bahia, 2002.

Revista Periferia, v.10, n.1, p. 179 - 201, Jan./Jun. 2018 